\title{
Oral Cancer Biomarkers - as Powerful Diagnostic and Prognostic Tools
}

\author{
Palak Ahuja* \\ Department of Biotechnology, Faculty of Science, Jamia Hamdard, New Delhi-110062, India \\ *Corresponding author
}

\begin{abstract}
A B S T R A C T
Keywords

Oral cancer, OSCC,

Premalignant

lesion,

Biomarkers, cytokines,

Article Info

Accepted:

22 December 2015

Available Online:

10 January 2016

Oral cancer, a complex multistage process, is predominant in the Southeast Asian countries, owing to increased consumption of smokeless tobacco, tobacco, alcohol and Human papilloma virus type 16 infection. Oral cancers tends to advance from the non-healing pre-malignant lesions, namely, leukoplakia, erythroplakia and oral sub-mucous fibrosis. However, the major challenge encountered is to predict which pre-cancerous lesion might transform into oral carcinoma, indicating the importance of protein based molecular markers or biomarkers. Several biomarkers, with diagnostic, prognostic and therapeutic value for oral carcinogenesis have been identified till date and this review focuses on the current understanding of the potential OSCC biomarkers, such as Endothelin 1, salivary transferrin, zinc finger protein 510, microRNA: miR-31 as well as cytokine biomarkers, including
\end{abstract}

\section{Introduction}

Oral carcinogenesis is considered to be a highly complex, molecular and histologically multistage process, which is often localized in the oral cavity, may metastasize and spread out resulting in the onset of Squamous Cell Carcinoma of Head and Neck (SCCHN). Among all the oral cancers, the frequency with which OSCC (Oral Squamous Cell Carcinoma) (arising from the lining mucosa) occurs is the highest [1-3], making OSCC the sixth most widespread malignancy [4].
In spite of this, incidence of Oral Cancer is more predominant in the Southeast Asian countries [5] owing to excessive smokeless tobacco products consumption [6] as a consequence of nitrosamines mediated DNA adduct formation followed by uncontrolled proliferation [7]. One of the most important risk factor for the oral cancer to develop in western countries is the consumption of tobacco and alcohol independently or together [8, 9] (synergistic effect) or infection with human papilloma virus, 
particularly type 16 (HPV 16) [10].

Many of the OSCC's tend to advance from the pre-malignant lesions of the oral cavity $[11,12]$, where in the development of nonhealing ulcers i.e. leukoplakia (best known precursor lesion), erythroplakia or oral submucous fibrosis (OSF) is often followed by carcinogenesis upon chewing betel quid or HPV 16 infection $[13,14]$. This progression of premalignant lesion into a cancerous tissue is often distinguished by the identification of cytogenetic changes such as the loss of chromosomal $3 p$ region (a critical tumor suppressor gene region), resulting in a 3.8 fold higher risk of carcinogenesis [1517]. However the major challenge encountered is to predict which premalignant lesion might transform into carcinoma. In order to predict this transformation, the discovery of protein based biological markers have been proposed to be of significant value [18].

This article, therefore focuses on the current understanding of the potential OSCC biomarkers with the intention of identifying precancerous lesion with a threat of malignant conversion via non-invasive method.

\section{Carcinogenic Biomarkers}

\section{Potential for Cytokines as Salivary biomarkers}

Cytokines, a group of proteins affecting the conduct of cells diversely, is known to bind to specific cell membrane receptors and thereby persuade a number of activities in a cell [19]. The salivary cytokine levels can be effectively utilized as markers of cell proliferation and therefore are of particular interest in the early diagnosis of oral carcinogenesis. Out of all, the most widely studied cytokines include interleukins- 6 and
8, interleukins -4 and -10 , epidermal growth factor (EGF), tumor necrosis factor (TNF), vascular endothelial growth factor (VEGF) (angiogenic factor) and endothelin (ET) [20].

Interleukin 6 (IL-6), one of the main cytokines found to be elevated in the serum samples of patients suffering from head and neck cancer patients when compared to the healthy controls or patients suffering from non-threatening diseases, is capable of independently forecasting tumor metastasis by the regulation of cytokine and protease mediated complex networks [21, 22]. Interestingly, IL-6 has shown to promote the proliferation of tumor cells in numerous tumor cell lines such as human cervical carcinoma [23]. The characteristic role of IL-6 in promoting proliferation, inhibiting apoptosis and tumor angiogenesis is mediated via its interaction with its receptor 'IL-6R $\alpha$ ' and co-receptor glycoprotein 130 (gp130) thereby activating JAK/STAT signaling pathway (Fig. 1) [24] followed by alterations in the transcription levels of several genes such as the ones regulating apoptosis- BcL-XL (B cell lymphomaextra-large), c-myc, XIAP (X-linked inhibitor of apoptosis protein) and Fas [25, 26]. Also, IL-6 is known to influence the binding of STAT3 and p53, positively, rendering p53 not capable of regulating apoptosis [25], making STAT 3 a chief regulator of the IL-6 stimulated cell growth,proliferation and tumor metastasis [27]. Apart from influencing the genes and proteins involved in apoptosis, IL-6 is also known to promote hyper-methylation of the promoter via specifically DNMT3b, leading to tumor metastasis in the case of pancreatic ductal adenocarcinoma, indicating that IL-6 is capable of inducing epigenetic changes $[28,29]$. One of the recent studies in the year 2011, is in coherence with the available data concerning IL-6 mediated hyper- 
methylation. The study suggested that the LINE-1 sequences, in the oral cavity, found to be hyper-methylated leading to chromosomal instability followed by tumorigenesis was a result of IL- 6 mediated inflammation [30]. Another study in the year 2015 also displayed increased levels of IL-6 in the saliva of patients suffering from oral cancer when compared to the control group [31]. Since, IL-6 is one of the essential mediators of oral cancer development, it is therefore implicated in early diagnosis of premalignant lesions[32].

Tumor Necrosis Factor $\alpha($ TNF- $\alpha)$, an

inflammatory mediator, is found to be associated with carcinogenesis, where it plays a more crucial role in the initiation of carcinogenesis including angiogenesis as well as invasion, when compared to its

progression [33-35]. TNF- $\alpha$, upon interacting with either of the two receptors -

TNF- $\alpha$ receptor-1 (TNF- $\alpha \mathrm{R} 1)$, universally

expressed and TNF- $\alpha$ receptor-2 (TNF- $\alpha \mathrm{R}$ -

2 ), expressed chiefly in the immune cells [36], is capable of exerting its biological function via multiple signaling pathways including the activation of NF- $\kappa \mathrm{B}$, a major signal for cell survival as well as JNK activation responsible for cell death, making TNF mediated signaling a double dealer with regard to cancer (Fig. 1) [37]. However, the response of a cell towards

TNF- $\alpha$ is largely dependent on its concentration [38]. High concentrations of TNF- $\alpha$ induced an anti-tumoral response in case of sarcoma murine model [39], despite being cytotoxic, whereas, low and sustained concentrations of $\mathrm{TNF}-\alpha$ facilitate tumorigenesis by activating $\mathrm{NF}-\kappa \mathrm{B}$ pathway $[40,41]$. Also, studies report the

involvement of TNF- $\alpha$ in inducing reactive

oxygen species (ROS) along with reactive nitrogen species production followed by DNA damage and tumorigenesis [42, 43]

and therefore, TNF- $\alpha$ has been associated with cancer, for example enhanced levels of TNF- $\alpha$ has been noticed in the H. pylori

positive gastric pre-neoplastic lesions [44, 45]. Similar observations were made with respect to OSCC, where in prolonged

exposure of TNF- $\alpha$ enhanced the cancer

stem cell phenotypes [46]. Also, the 
concentrations of TNF- $\alpha$ in the saliva of

OSCC patients was higher when compared to that of the control group [47], making

TNF- $\alpha$ a potential molecular marker for the

purpose of early diagnosis of OSCC, as it is not only involved in the initiation of cancer, but also in its progression, as reported in a

recent study which stated that TNF- $\alpha$ is

capable of inducing the stabilization of Snail, a transcriptional repressor followed by activation of NF- $\kappa$ B pathway in the OSCC cell lines [48].

\section{Transforming Growth Factor $\beta$ (TGF- $\beta)$,}

well known for its anti-inflammatory as well as immune suppressing properties, exists in

three isoforms - TGF- $\beta 1$, TGF- $\beta 2$ and TGF-

$\beta 3$ under its physiological form and interacts

with its type II receptor, TGF- $\beta$ RII, leading to phosphorylation of type I receptor, $\operatorname{TGF} \beta$

RI, followed by the activation of SMAD mediated transcription [49, 50]. With

respect to cancer, TGF- $\beta$ inhibits the

progression of cell cycle, promotes apoptosis and acts as a tumor suppressor, during the early stages, by up regulating $\mathrm{p} 21$, cyclin dependent kinase inhibitor and down regulation of c-Myc (Fig. 1) [51]. However, it is known to enhance epithelialmesenchymal transition (EMT) followed by tumor metastasis [52]. Transforming growth factor- $\beta 1$ (TGF- $\beta 1$ ), which is found to be elevated in the human OSCC tumors when compared to the normal tissue of head and neck region[53], is responsible for the promotion of tumorigenesis and increase in the metastasis $[54,55]$. In one of the studies, it was observed that the targeted expression of TGF- $\beta 1$ in the epithelial tissue of head and neck region of transgenic mice lead to hyperplasia followed by tumor progression in the oral cavity [53]. A recent study suggested that TGF- $\beta 1$ plays an important role in regulation of matrix metallopeptidase 9(MMP-9) expression levels, chief mediator of OSCC invasion, by enhancing the expression of Snail in the OSCC cells [56]. Therefore, TGF- $\beta 1$ mediates tumor progression by the regulation of EMT as well as by increasing the expression of MMP-9, making it a potential biomarker.

Endothelin 1 and its role in Oral Carcinogenesis

Endothelin 1 (ET-1), a small peptide of 21 amino acids with cytokine like activity, comprises a family of small peptides, ET-1 
(expressed chiefly in endothelial cells), ET-2 (expressed in kidney as well as intestine) and lastly ET-3 (expressed primarily in brain) $[57,58]$, with ET-1 being the most common form of circulating endothelin. Endothelins mediate their effect by interacting with the superfamily of Gprotein coupled cell surface receptorsendothelin receptor A (ETAR) as well as endothelin receptor B (ETBR) [59], with most functions of ET peptides mediated via endothelin receptor A [60]. Under physiological conditions ET peptides are known to play an important role in the regulation of vascular system, cell proliferation, tissue differentiation as well as development and hormone production [61]. Interestingly, endothelin system is also well known for its contribution to the growth and progression of tumors in many cancer types, for instance, ovarian, colorectal, prostatic and OSCC [62-64]. As per the data available, it has been concluded that ET-1, its receptor- endothelin receptor A and B are overexpressed in OSCC, where in ET-1 mediates cell growth and proliferation [65]. ET-1, in the oral cavity, is also responsible for stimulating the release of ADAM17, a bioactive ligand, from fibroblast which is followed by its interaction with cell surface receptor-EGFR on the cancer cells, thereby increasing the cancer cell migration as well as invasion [66, 67]. Apart from this, the binding of ET-1 with its receptor- ETAR also promotes EMT [68].

In one of the studies in the year 2007, a significant increase in the ET-1 was observed in the HSC3, an OSCC cell line, where in the intra-tumoral administration of BQ-123, an ETAR antagonist, had a similar analgesic effect, as in the case of morphine administration in OSCC mouse model [69]. Another study in the year 2010 provided similar results, where in ET-1 levers were found to be two-fold increase in OSCC cells when compared to normal (control) oral keratinocytes and the treatment of OSCC cells with BQ-123 persuaded the production of b-endorphin and leu-enkephalin, suggesting the analgesic effects of BQ-123 indicating that analgesic effects of this antagonist [70]. Therefore, the utilization of the antagonists, having selectivity for ETAR, ETBR or both represent a promising option for cancer therapy [71]. Interestingly, it has been observed that ETAR antagonists can be orally administered via clinical studies [72].

\section{Salivary Transferrin as a Molecular Marker}

Transferrin (Trf), a blood plasma protein known for its iron binding properties, mediates the transportation of iron to almost all the tissues from the absorption sites duodenum along with red blood cell recycling macrophages [73].The chief source of transferrin is the liver. Transferrin is also present in placenta, kidney, mammary glands, stomach, immune system cells, heart, lungs and tumor cells in detectable amounts [74-78]. The expression level of Trf receptor on the surface of proliferating cells is higher when compared to the absent or rare expression of $\operatorname{Trf}$ receptor on the surface of resting cells [79]. Also, studies suggest that upon directing the anti-Trf receptor antibodies against the receptor results in the inhibition of cell growth [80]. Therefore, with respect to cancer, the association of expression levels of $\operatorname{Trf}$ receptor with cell proliferation, provides a promising target for both diagnostic and therapeutic purpose [73]. One of the recent studies report transferrin receptor 1 (TFRC1) as a direct downstream transcriptional target of the proto-oncogene, c-MYC, suggesting the reason behind the over-expression of TFRC1 in tumorous cells [81]. 
The specific relationship between the transferrin levels and OSCC was observed recently i.e. in the year 2010 by a group of scientists. In this study, the salivary proteomic profile of the OSCC patients was compared to that of the OSCC free control group. The results indicated that the transferrin levels are elevated in the saliva of OSCC patients and a significant increase in the salivary transferrin levels resulted in a simultaneous increase in the tumor size, indicating the importance of salivary transferrin as an early stage OSCC biomarker [82].

\section{Zinc Finger Protein 510 as a Novel Biomarker}

Zinc Finger Proteins (ZNF), one of the most abundant eukaryotic proteins, are responsible for extraordinarily diverse functions such as transcriptional activation, DNA recognition, RNA packaging, protein folding along with its assembly, regulation of apoptosis and lipid binding [83]. Also, ZNFs are capable of regulating cell growth, proliferation and its differentiation [84]. A number of recent studies suggest new zinc finger proteins with novel structural and functional properties [83], for instance studies report that ZNF652 regulate CBFA2T3 protein leading to the promotion of tumorigenesis [85]. Another zinc finger protein, ZNF278 also activates cell growth and proliferation and its knockdown leads to suppression of cell proliferation [86]. Also, ZNF410 is found to be associated with esophageal squamous cell carcinoma in humans [87]. All of this data regarding the ZNF expression level suggest the importance of $\mathrm{ZNF}$ as a biomarker candidate in different tumor types. ZNF 510 has been a well-known biomarker for breast cancer as suggested in a studies conducted in the year 2010 and 2011 [88, 89]. A recent study
(2011) for the first time reported the role of ZNF 510 as a potential biomarker for OSCC by comparing the salivary proteomic profiles of OSCC patients with the control group. The results indicated a 2919 Da peptide to be significantly increased in OSCC patients saliva when compared to the control group, which upon sequencing corresponded to the 176-199 residues of the peptide ZNF510, making it a potential salivary biomarker for OSCC patients [90].

\section{microRNA, as a Potential Biomarker for Oral Cancer}

MicroRNAs (miRNAs), a non-coding RNA of 19-24 nucleotide, is known to regulate translation along with the degradation of target mRNAs [91]. The recent finding of diverse miRNAs play a number of important functions including cell growth and differentiation, apoptosis, response towards stress, glucose secretion and immune response [92, 93]. Also, miRNAs have been reported to be differentially expressed in cancer cells when compared to that of normal cells, making miRNA as a potential biomarker for diagnostic and therapeutic purpose [91, 94]. Furthermore, the miRNA expression level in cancer cells exhibits ten to hundred fold change, when compared to that of mRNA [95]. miRNA is also found to be associated with vascular invasion, for instance miR-21 along with miR-184 were found to be associated with tumorigenesis in OSCC [96]. Another study demonstrated that the levels of miRNAs- miR-200a and miRNA $125 \mathrm{~s}$ in the saliva of OSCC patients when compared to that of healthy controls was found to be significantly low. Also, miR-125a and its homologue upon being transiently transfected reduced ERBB2 and ERBB3, oncogenic protein in human breast cancer cell line, SKBR3 cells [97, 98] 


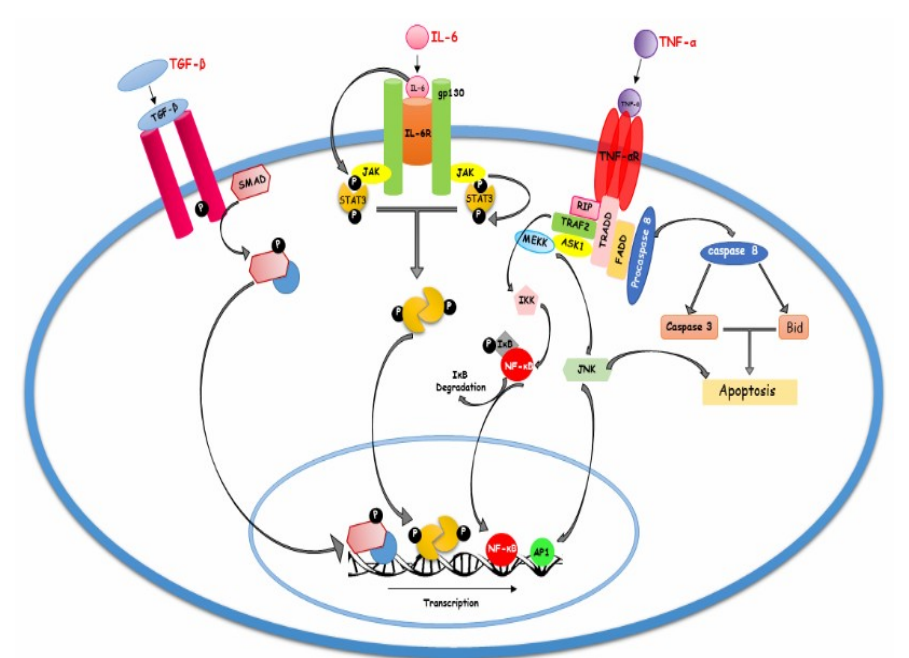

Figure.1 Mechanism of action of cytokine biomarkers: Interleukin 6 (IL 6), tumor necrosis factor $\alpha$ (TNF $\alpha)$ and transforming growth factor $\beta$ (TGF $\beta) \mid$ RIP: Ribosome interacting Protein; TRAF 2: TNF Receptor Associated Factor 2; ASK1: Apoptosis signal-regulating kinase 1; TRADD: Tumor necrosis factor receptor type 1-associated DEATH domain protein; FADD: Fas Associated Death Domain Protein; MEKK: MAP Kinase KinaseKinase; Bid: BH3 interactingdomain death agonist; gp130: Glycoprotein 130 IKK: IкB kinase; IкB: Nuclear Factor of kappa Light Polypeptide Gene Enhancer in B-Cells Inhibitor; ; NF- $\kappa \mathrm{B}$ : Nuclear factor kappa-lightchain-enhancer of Activated B Cells; JNK: c-Jun N-terminal kinases JAK: Janus Kinase; STAT: Signal Transducer and Activator of Transcription.

Additionally, a study reported increased expression level of miRNA, miR-31 in breast carcinogenesis by regulating a diverse number of genes [99]. Similar results were reported by a study conducted in the year 2010, but in case of OSCC, where in plasma as well as salivary levels of miR-31 were compared in patients suffering from OSCC to that of the control group. The results indicated an increased levels of plasma miR31 in the OSCC patients, with miR-31 levels declining after the surgery. [100, 101]. Therefore it can be concluded the plasma levels of miR-31 can be of significant value in distinguishing OSCC from the premalignant lesions.

With the current understanding of the pathways associated with tumor initiation and progression, the identification of the potential protein based biomarkers and its utilization for the purpose of diagnosis in clinical practice is sure to not only design a treatment plan for oral cancer, but also advance our knowledge regarding the understanding of carcinogenesis thereby allowing the development of drugs with higher effectively and specificity towards the disease. Also, the identification of protein based biomarkers for oral cancer detection is of a significant value as it allows the detection/diagnosis of oral cancer not only at an early stage, but also in a noninvasive method. However, there still exists issues such as lack of standardization etc. which need to be fixed via further research.

\section{References}

1. Tanaka T, Tanaka M and Tanaka T. Oral Carcinogenesis and oral cancer chemoprevention: A Review. Pathology 
Research International. 2011; Article ID 431246, 10 pages.

2. Jemal A, Siegal R, Ward E, Hao Y, Xu $\mathrm{J}$ and Thun MJ. Cancer statistics, 2009. CA Cancer Journal for Clinicians. 2009;59 (4): 225-249

3. Wan-Yu Lo, Ming-HsuiTsai,Yuhsin Tsai, Chun-Hung Hua, Fuu-Jen Tsai, Shiuan-Yi Huang et al. Identification of over-expressed proteins in oral squamous cell carcinoma (OSCC) patients by clinical proteomic analysis. ClinicaChimicaActa. 2007; 376: 101107.

4. Nagpal JK, Das BR. Oral cancer: reviewing the present understanding of its molecular mechanism and exploring the future directions for its effective management. Oral Oncology. 2003; 39: 213-221

5. Benzian H. NCDs and Oral Cancer: Rationale for Inclusion in SEAR NCD Action Plan and Voluntary Targets. Regional office for South East Asia, World Health Organization. 2013

6. Boffetta P, Hecht S, Gray N, Gupta P and Straif K. Smokeless tobacco and cancer. The Lancet Oncology. 2008;9(7): 667-675.

7. Xue J, Yang S and Seng S. Mechanisms of Cancer Induction by TobaccoSpecific NNK and NNN. Cancers. 2014; 6: 1138-1156

8. Jeng JH, Chang MC and Hahn LJ. Role of areca nut in betel quid-associated chemical carcinogenesis: current awareness and future perspectives. Oral Oncology. 2001; 37(6): 477-492

9. Warnakulasuriya S, Sutherland G and Scully C. Tobacco, oral cancer, and treatment of dependence. Oral Oncology. 2005; 41(3): 244-260

10. Paz IB, Cook N, Odom-Maryon T, Xie Y, Wilczynski SP. Human papillomavirus (HPV) in head and neck cancer: an association of HPV-16 with squamous cell carcinoma of Waldeyer'stonsillar ring. Cancer. 1997; 9: 595-604.

11. Silverman S Jr, Gorsky M, Lozada F. Oral leukoplakia and malignant transformation. A follow-up study of 257 patients. Cancer. 1984; 53(3): 5638

12. Silverman S Jr. Observations on the clinical characteristics and natural history of oral leukoplakia. J Am Dent Assoc. 1968; 76(4):772-7.

13. Nair $\mathrm{U}$, Bartsch $\mathrm{H}$ and Nair J. Alert for an epidemic of oral cancer due to use of the betel quid substitutes gutkha and pan masala: a review of agents and causative mechanisms. Mutagenesis. 2004; 19(4) 251-262

14. Neville BW and Day TA. Oral Cancer and Precancerous Lesions. CA Cancer J Clin. 2002; 52:195-215

15. Reibel J. Prognosis of Oral premalignant lesions: significance of clinical, histopathological, and molecular biological characteristics. Crit Rev Oral Biol Med. 2003; 4(1): 4762

16. Kim MM and Califano JA. Molecular pathology of head-andneck cancer. Int $\mathrm{J}$ Cancer. 2004; 112: 545-553

17. Rosin MP, Cheng X, Poh C, Lam WL, Huang Y, Lovas $\mathrm{J}$ et al. Use of allelic loss to predict malignant risk for lowgrade oral epithelial dysplasia. Clin Cancer Res. 2000; 6: 357-362

18. Reibel J. Prognosis of Oral premalignant lesions: significance of clinical, histopathological, and molecular biological characteristics. Crit Rev Oral Biol Med. 2003; 4(1): 4762

19. JanewayCA Jr., Travers P, Walport M and Shlomchik MJ.Immunobiology: The Immune System in Health and Disease, ChurchillLivingstone, 199 
20. Schapher M, Wendler O and Gr“oschl. Salivary cytokines in cell proliferation and cancer. ClinicaChimicaActa. 2011; 412(19-20): 1740-1748

21. Lederle W, Depner S, Schnur S, Obermueller E, Catone N, Just A, et al. IL-6 promotes malignant growth of skin SCCs by regulating a network of autocrine and paracrine cytokines. Int $\mathbf{J}$ Cancer. 2011; 128:2803-14. 30.

22. Duffy SA, Taylor JM, Terrell JE, Islam M, Li Y, Fowler KE, et al. Interleukin-6 predicts recurrence and survival among head and neck cancer patients. Cancer. 2008; 113:750-7.

23. Tamura S, Ouchi KF, Mori $K$ et al. Involvement of human interleukin 6 in experimental cachexiz induced by a human uterine cervical carcinoma xenograft. Clinical Cancer Research. 1995; 1(11): 1353-1358

24. Hodge DR, Hurt EM and Farrar WL. The role of IL-6 and STAT3 in inflammation and cancer. European Journal of Cancer. 2005; 41(16): 25022512,

25. GuoY,Xu F, Lu T, Duan Z B, Zhang Z. Interleukin-6 signaling pathway in targeted therapy for cancer. Cancer Treatment Reviews. 2012; 38: 904-910

26. Darnell Jr JE. STATs and gene regulation. Science 1997;277:1630-5

27. $\mathrm{Yu} \mathrm{H}$ and Jove $\mathrm{R}$. The STATs of cancer- new molecular targets come of age. Nat Rev Cancer. 2004; 4: 97-105

28. Fukushima N, Sato N, Sahin F, Su GH, Hruban RH and Goggins M. Aberrant methylation of suppressor of cytokine signalling-1 (SOCS-1) gene in pancreatic ductal neoplasms. $\mathrm{Br} \mathrm{J}$ Cancer. 2003; 89: 338-43. 30.

29. Braconi $C$, Huang $N$, Patel $T$. MicroRNAdependent regulation of DNA methyltransferase-1 and tumor suppressor gene expression by interleukin-6 in human malignant cholangiocytes. Hepatology 2010; 51:881-90.

30. Gasche JA, Hoffmann J, Boland CR and Goel A. Interleukin-6 promotes tumorigenesis by altering DNA methylation in oral cancer cells. International Journal of Cancer. 2011; 129, 1053-1063

31. Radulescu R, Totan A, Calenic B, Totan C, Greabu M.Biomarkers of Oxidative Stress, Proliferation, Inflammation and Invasivity in Saliva from Oral Cancer Patients. Journal of Analytical Oncology. 2015; 4(1): 52-57.

32. Bano S, David MP, Indira AP. Salivary biomarkers for oral squamous cell carcinoma: An overview. IJSS Case Reports \& Reviews 2015; 1(8):39-45.

33. Popa C, Netea MG, Van RielP. L. C. M., Van Der MeerJ. W. M. and.

StalenhoefA. F. H. The role of TNF $\alpha$ in

chronic inflammatory conditions, intermediary metabolism, and cardiovascular risk.Journal of Lipid Research. 2007; 48 (4), 751-762.

34. Moore J, Owens DM, Stamp G et al. Mice deficient in tumor necrosis factoralpha are resistant to skin carcinogenesis. NatureMedicine. 1999; 5 (7): 828-831

35. Szlosarek P, Charles KA andBalkwill

FR. Tumournecrosis factor $\alpha$ as a tumor

promoter. European Journal of Cancer. 2006; 42 (6): 745-750

36. Chen G and Goeddel DV. TNF-R1 signaling: a beautiful pathway. Science. 2002; 296 (5573):1634-1635.

37. WANG X. and LIN Y. Tumor necrosis factor and cancer, buddies or 
foes? ActaPharmacologicaSinica,2008; 29(11), 1275-1288

38. Ohri CM, Shikotra A, Green RH, Waller DA and BraddingP. Tumor necrosis factor-alpha expression in tumor is lets confers survival advantage in non-small celllung cancer. BMC Cancervol.2010; 10, article323.

39. Havell EA, Fiers W and North RJ. The anti-tumor function of tumor necrosis factor (TNF)-I. Therapeuticaction of TNF against an established murine sarcoma is indirect, immunologically dependent, and limited by severe toxicity. Journal of Experimental Medicine. 1988; 167 (3): 1067-1085.

40. Balkwill F. Tumor necrosis factor and cancer. Nat Rev Cancer.2009; 9(5):36171

41. Balkwill F. TNF-alpha in promotion and progression of cancer. Cancer Metastasis Rev.2006; 25 (3):409-16.

42. Woo $\mathrm{CH}$, Eom YW, Yoo MH et al.

Tumor necrosis factor- $\alpha$ generates

reactive oxygen species via acytosolicphospholipase A2-linked cascade. Journal of Biological Chemistry. 2000; 275 (41): 3235732362.

43. Hussain SP, Hofseth LJandHarris CC. Radicalcausesof cancer. Nature Reviews Cancer. 2003; 3 (4): 276-285.

44. Noach LA, Bosma NB, Jansen J, Hoek FJ, Van Deventer S. J. H. and Tytgat

G.N.J. Mucosal tumor necrosis factor $\alpha$ interleukin-1 $\beta$ and interleukin-8

production in patients with helicobacter pylori infection. Scandinavian Journal of Gastroenterology. 1994; 29 (5) 425429.

45. Suganuma M, Watanabe T, Yamaguchi K, Takahashi A and Fujiki H. Human gastric cancer development with TNF-

ainducing protein secreted from

Helicobacter pylori. Cancer Letters. 2012; 322 (2): 133-138

46. Lee SH,Hong HS, Liuetal ZX. TNF- $\alpha$

enhances cancer stem cell-like phenotype via Notch-Hes1 activation in oral squamous cell carcinoma cells. Biochemical and Biophysical Research Communications. 2012; 424 (1): 58-64.

47. SahebJamee M, Eslami M., Moghadam F.A andSarafnejad A. Salivary concentration of TNF $\alpha$, IL $1 \alpha$, IL6, and IL8 in oral squamous cell carcinoma. Med Oral Patol Oral Cir Bucal.2008; 1; 13(5):E292-5.

48. Zhou, J-P., Gao Z-L, Zhou M-L, He-Y, $\mathrm{Xu}$ X-H, Tao D-T et al. Snail interacts with Id 2 in the regulation of TNF- $\alpha$ induced cancer cell invasion and migration in OSCC. American Journal of Cancer Research. 2015; 5(5), 1680 1691. 
49. Santibãnez JF, Quintanilla M

andBernabeu C. TGF $\beta /$ TGF- $\beta$ receptor

system and its role in physiological and pathological conditions. Clinical Science. 2011; 121 (6): 233-251.

50. J.Massagu'e. TGF beta in cancer. Cell. 2008; 134 (2): 215-230.

51. Malliri A, Andrew Yeudall W, Nikolic M, Crouch DH, Kenneth Parkinson EandOzanne B. Sensitivity to

transforming growth factor $\beta 1$-induced

growth arrest is common in human squamous cell carcinoma cell lines: cMYC down regulation and p21 (waf1) induction are important early events. Cell Growth and Differentiation. 1996; 7 (10): 1291-1304.

52. Morrison CD, Parvani JG and Schiemann WP. The relevance of the

TGF- $\beta$ Paradox to EMT-MET

programs. Cancer Letters. 2013; 341 (1): $30-40$

53. Lu SL, Reh D, Li AG et al. Overexpression of transforming growth factor $\beta 1$ in head and neck epithelia results in inflammation, angiogenesis, and epithelial hyper proliferation. Cancer Res. 2004; 64:4405-10.

54. Akhurst RJ, Derynck R. TGF- $\beta$ signaling in cancer $-a$ double-edged sword. Trends Cell Biol. 2001; 11:S4451.
55. Shi $Y$ andMassague J. Mechanisms of TGF- $\beta$ signaling from cell membrane to the nucleus. Cell. 2003; 113:685-700.

56. Sun L, Diamond ME, Ottaviano AJ, Joseph MJ,Ananthanarayan $\mathrm{V}$ and Munshi HG. Transforming Growth Factor- $\beta 1$ Promotes Matrix Metalloproteinase-9-Mediated Oral Cancer Invasion through Snail Expression. Mol Cancer Res. 2008; 6; 10

57. Yanagisawa M, Kurihara H, Kimura S, Tomobe Y, Kobayashi M, Mitsui Y, et al. A novel potent vasoconstrictor peptide produced by vascular endothelial cells. Nature. 1988; 332:411-5.

58. Barton $M$ and Yanagisawa $M$. Endothelin: 20 years from discovery to therapy. Can J PhysiolPharmacol. 2008;86:485-98

59. BagnatoA andNatali PG. Endothelin receptors as novel targets in tumor therapy. J Transl Med. 2004; 2:16.

60. Guise TA, Yin JJ and Mohammad KS. Role of endothelin-1 in osteoblastic bone metastasis. Cancer. 2003; 97(S3):779-84.

61. Russo A, Bronte G, Rizzo S, Fanale D, Di Gaudio F, Gebbia N, et al. Antiendothelin drugs in solid tumors. Expert OpinEmerg Drugs. 2010; 15(1):27-40.

62. BhallaA, Haque S, Taylor I, Winslet M andLoizidou M. Endothelin receptor antagonism and cancer. Eur $\mathbf{J}$ Clin Invest. 2009; 39(S2):74-7.

63. Bagnato $\mathrm{A}$, Spinella $\mathrm{F}$ andRosanò $\mathrm{L}$. Emerging role of the axis in ovarian tumor progression. EndocrRelat Cancer. 2005; 12:761-72.

64. Bagnato A, Spinella F, Rosanò L. The endothelin axis in cancer: the promise and the challenges of molecularly target therapy. Can J PhysiolPharmacol. 2008; 86:473-84. 
65. Awano S, Dawson LA, Hunter AR, Turner AJ andUsmani BA. Endothelin system in oral squamous carcinoma cells: Specific siRNA targeting of ECE1 blocks cell proliferation. Int J Cancer. 2006; 118:1645-52

66. Hinsley EE, Hunt S, Hunter KD, Whawell SA, Lambert DW. Endothelin1 stimulates motility of head and neck squamous carcinoma cells by promoting stromal-epithelial interactions. Int $\mathbf{J}$ Cancer. 2012; 130:40-7

67. Barr S, Thomson S, Buck E, Russo S, Petti F, Sujka-Kwok I et al. Bypassing cellular EGF receptor dependence through epithelial-to-mesenchymal-like transitions. ClinExp Metastasis. 2008; 25:685-93.

68. Rosano L, Cianfrocca R, Spinella F, Di Castro V, Nicotra MR, Lucidi A, et al. Acquisition of chemoresistance and EMT phenotype is linked with activation of the endothelin A receptor pathway in ovarian carcinoma cells. Clinical Cancer Res. 2011; 17:2350-60.

69. Schmidt BL, Pickering V, Liu S, Quang P, Dolan J, Connelly ST, Jordan RC. Peripheral endothelin- A receptorantagonism attenuates carcinoma induced pain. 2007; 11: 40614

70. Quang PN and Schmidt BL. Endothelin-A receptor antagonism attenuates carcinoma-induced pain through opioids in mice. The J Pain 2010.

71. Kusserow $\mathrm{H}$ and Unger T. Vasoactive peptides, their receptors and drug development. Basic ClinPharmacolToxicol. 2004; 94: 5-12

72. Bagnato $A$ and Rosano L. The endothelin axis in cancer. Int $\mathrm{J}$ Biochem Cell Biol. 2008; 40: 1443-51

73. Macedo MF and Sousa MD. Transferrin and the Transferrin Receptor: Of Magic Bullets and Other Concerns.
Inflammation \& Allergy - Drug Targets. 2008; 7: 41-52

74. Morgan, E.H. Transferrin and Transferrin iron. In: Jacobs, A., and Worwood, M. (eds). Iron in Biochemistry and Medicine. Academic Press, London. 1974

75. Aldred AR, Dickson PW, Marley PD, Schreiber GJ. Distribution of transferrin synthesis in brain and other tissues in the rat. Biol. Chem., 1987, 262, 5293.

76. De Sousa M, Breedvelt F, DynesiusTrentham R, Trentham D, Lum $\mathrm{J}$ and Ann. NY. Iron, Iron binding proteins and immune system cells. Acad. Sci. 1988; 526, 310.

77. Vandewalle B, Hornez L, Revillion, F and Lefebvre J. Secretion of transferrin by human breast cancer cells.Biochem. Biophys. Res. Commun. 1989; 163, 149.

78. Vostrejs M, Moran PL and Seligman PA. Transferrin synthesis by small cell lung cancer cells acts an autocrine regulator of cellular proliferation. J. Clin. Invest. 1988, 82, 331

79. Sutherland R, Delia D, Schneider C, Newman R, Kemshead Jand Greaves M. Ubiquitous cell surface glycoprotein on tumor cell is proliferation associated receptor for transferrin. Proc. Natl. Acad. Sci. U.S.A. 1981; 78, 4515- 4519

80. Trowbridge IS, Newman RA, Domingo DL and Sauvage C. Transferrin receptor: structure and function. Biochem. Pharmacol. 1984; 6, 925-932

81. O'Donnell KA, Duonan Yu, Zeller KI, Kim JW, Racke F, Tikhonenko ATet al. Activation of Transferrin Receptor 1 by c-Myc Enhances Cellular Proliferation and Tumorigenesis. Molecular and cellular biology. 2006; 26 (6): 23732386

82. Jou YJ, Lin CD, Lai CH, Chen CH, Kao JY, Chen SY, et al. Proteomic identification of salivary transferrin as a 
biomarker for early detection of oral cancer. AnalyticaChimicaActa. 2010; 681: 41-48

83. Laity JH, Lee BM, Wright PE. Zinc finger proteins: new insights into structural and functional diversity. Current Opinion in Structural Biology. 2001;11, Issue 1, 1: 39-46

84. Ladomery $\mathrm{M}$ and Dellaire $\mathrm{G}$. Multifunctional zinc finger proteins in development and disease. Ann Hum Genet. 2002; 66: 331-42

85. Kumar R, Manning J, Spendlove HE et al. ZNF652, a novel zinc finger protein interacts with the putative breast tumor suppressor CBFA2T3 to repress transcription. Mol Cancer Res. 2006; 4: 655-65

86. Tian X, Sun D, Zhang Y, Zhao S, Ziong $\mathrm{H}$ and Fang J. Zinc finger protein 278, a potential oncogene in human colorectal cancer. ActaBiochemBiophys Sin (Shanghai). 2008; 40: 289-96

87. Du XL, Hu H, Lin DC, et al. Proteomic profiling of proteins dysregulted in Chinese esophageal squamous cell carcinoma. J Mol Med. 2007;85:863-75

88. Mosca E, Alfier R, Merelli I, Viti F, Calabria A and Milanesi L. A multilevel data integration resource for breast cancer study. BMC Syst Biol. 2010; 4:76

89. Anderson KS, Sibani S, Wallstrom G, et al. Protein microarray signature of autoantibody biomarkers for the early detection of breast cancer. J Proteome Res 2011; 10:85-96.

90. Jou YJ, Lin CD, Lai $\mathrm{CH}$, Tang $\mathrm{CH}$, Huang SH, Tsai MH, et al. Salivary zinc finger protein 510 peptide as a novel biomarker for detection of oral squamous cell carcinoma in early stages. ClinicaChimicaActa. 2011; 412: $1357-1365$
91. Bartel DP. MicroRNAs: target recognition and regulatory functions. Cell. 2009; 136: 215-233

92. Phillips JR, Dalmay T and Bartels D. The role of small RNAs in abiotic stress. FEBS Lett. 2007; 581:3592-7. 25.

93. Taganov KD, Boldin MP and Baltimore D. MicroRNAs and immunity: tiny players in a big field. Immunity 2007; 26:133-7.

94. Lu J, Getz G, Miska EA, et al. MicroRNA expression profiles classify human cancers. Nature. 2005;435:8348

95. Jiang J, Lee EJ, Gusev Y, Schmittgen TD. Realtime expression profiling of microRNA precursors in human cancer cell lines. Nucleic Acids Res. 2005;33:5394-403

96. Wong QW, Lung RW, Law PT et al. MicroRNA-223 is commonly repressed in hepatocellular carcinoma and potentiates expression of Stathmin1.Gastroenterology. 2009; 135: 25269.

97. Park N, Zhou H, Elashoff D, Henson BS, Kastratovic DA, Abemayor E et al. Salivary microRNA: Discovery, Characterization, and Clinical Utility for Oral Cancer Detection. Clin Cancer Res. 2001; 15(17)

98. Scott GK, Goga A, Bhaumik D, Berger CE, Sullivan CS and Benz CC. Coordinate suppression of ERBB2 and ERBB3 by enforced expression ofmicro-RNAmiR-125aormiR-

125b.JBiolChem 2007;282:1479-86

99. Valastyan S, Reinhardt F, Benaich $\mathrm{N}$ et al. A pleiotropically actingmicroRNA, miR-31, inhibits breast cancer metastasis. Cell. 2009; 137: 1032-1046

100. Liu CJ, Kao SY, Tu1 HF, Tsai MM, Chang KW and Lin SC. Increase of microRNA, miR-31 level in plasma could be a potential marker of oral 
cancer.Oral Diseases. 2010; 16, 360364.

101.Wong TS, Liu XB, Wong BY et al. Mature miR-184 as potential oncogenic microRNA of squamous cell carcinoma of tongue. Clin Cancer Res. 2008; 14: $2588-2592$.

\section{How to cite this article:}

Palak Ahuja. 2016. Oral Cancer Biomarkers - as Powerful Diagnostic and Prognostic Tools. Int.J.Curr.Microbiol.App.Sci.5(1): 209-220. http://dx.doi.org/10.20546/ijcmas.2016.501.019 